AL IBTIDA: JURNAL PENDIDIKAN GURU MI (2021) Vol 8 (2) : 252-262

DOI: http://dx.doi.org/10.24235/al.ibtida.snj.v8i2.8219

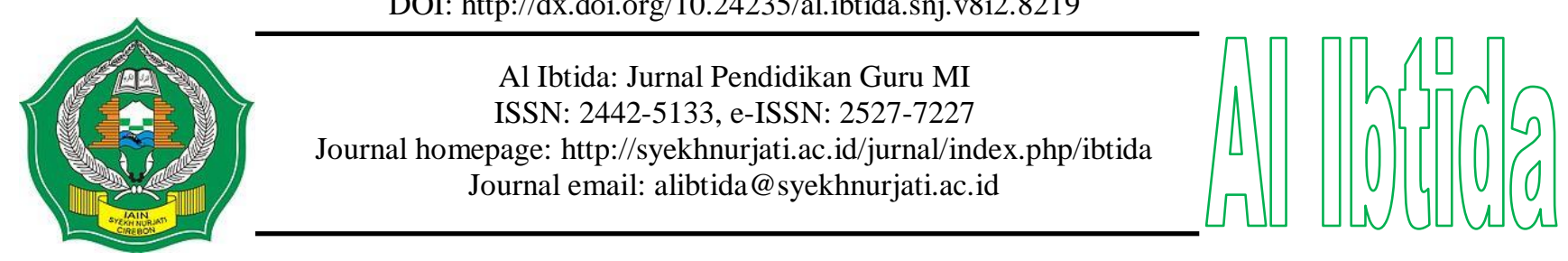

\title{
The Analysis of Higher Order Thinking Skills of Islamic Elementary School Students on Science Subject
}

\author{
Peni Susapti* \\ *Madrasah Ibtidaiyah Teacher Education Study Program, Faculty of Tarbiyah and Teacher Training, \\ Institut Agama Islam Negeri Salatiga, Indonesia. \\ Email: peni.susapti@iainsalatiga.ac.id \\ Muhammad Istiqlal** \\ **Mathematics Education Study Program, Faculty of Tarbiyah and Teacher Training, \\ Institut Agama Islam Negeri Salatiga, Indonesia. \\ Email: m.istiqlal@iainsalatiga.ac.id
}

Received: April 06 $6^{\text {th }}, 2021$. Accepted: October $18^{\text {th }}, 2021$. Published: October $30^{\text {th }}, 2021$.

\begin{abstract}
The study aims to analyze the students' higher order thinking skills (HOTS) in Science subjects at Islamic Elementary School in Salatiga, Indonesia. It is descriptive qualitative research. Using the nonprobability sampling with convenience sampling method, this study involved 120 students as the sample. The data were gathered using tests, questionnaires, Focus Group Discussions (FGD), and documentations. The descriptive analysis with percentile formula was used to analyze the data. The results indicated that the students' HOTS abilities were still at the low level. In Low Order Thinking Skills (LOTS) questions category, the students' ability to answer questions ranged from 0.6 to 0.9 (good). In Middle Order Thinking Skills (MOTS) questions category, the index of the students' abilities was 0.35 to 0.65 (the medium category). In HOTS questions category, the index of the students' abilities was 0.075 to 0.45 (the low category). Therefore, it is necessary to make efforts in improving the HOTS ability of Islamic Elementary School students.
\end{abstract}

Keywords: higher order thinking skills, Islamic elementary school students, science subject.

\begin{abstract}
Abstrak
Penelitian ini bertujuan untuk menganalisis keterampilan berpikir tingkat tinggi (HOTS) siswa pada mata pelajaran IPA di Madrasah Ibtidayah Kota Salatiga, Indonesia. Penelitian ini merupakan penelitian deskriptif kuantitatif. Dengan menggunakan nonprobability sampling dengan metode convenience sampling, penelitian ini melibatkan 120 siswa sebagai sampel. Data dikumpulkan dengan menggunakan tes, angket, Focus Group Discussion (FGD), dan dokumentasi. Analisis deskriptif dengan rumus persentil digunakan untuk menganalisis data. Hasil penelitian ini menunjukkan bahwa sebagian besar siswa mempunyai kemampuan HOTS berada pada level rendah. Pada soal kategori LOTS, kemampuan siswa untuk menjawab soal berkisar antara 0,6 sampai dengan 0,9 (baik). Pada kategori soal MOTS, indeks kemampuan siswa adalah 0,35 sd 0,65 (kategori sedang). Pada kategori soal HOTS, indeks kemampuan siswa adalah 0,075 sd 0,45 (kategori
\end{abstract}


rendah). Oleh karena itu perlu dilakukan usaha untuk meningkatkan kemampuan HOTS siswa di Madrasah Ibtidaiyah.

Kata kunci: keterampilan berpikir tingkat tinggi, siswa madrasah ibtidaiyah, pelajaran IPA.

\section{INTRODUCTION}

The achievement of Indonesian students in international competitions is still low. Based on the Organization for Economic Co-Operation and Development (OECD) data, the quality of education in Indonesia is ranked 371 (reading), 379 (mathematic), and 396 (science) (OEDC, PISA Database, 2018). Thus, the competence of Indonesian students at various levels needs to be improved, especially in developing the higher-order thinking skills. Therefore, the government encourages the inclusion of HOTS in the curriculum. The HOTS competencies include critical thinking, creative and innovative, communication skills, collaboration, and confidence. These 5 criteria are attached to the evaluation system in the national exam as the skills needed in the 21 st century (Ilham et al., 2020; Widyawati et al., 2021).

The government tries to improve the education quality to establish human resources who are able to compete with other developed countries through the implementation of 2013 Curriculum (Tobari et al., 2018). In this curriculum, students are encouraged to optimize the higher-order thinking skills on the cognitive aspects as well as the psychomotor and affective aspects (Fanani, 2018).

Innovation on learning to generate high-level skills requires adjustment on the assessment process. The type of assessment should be compatible with learning, focusing on the improvement of high-level skills. The assessment based on HOTS does not assess the students' high-level skills but it evaluates the target of competency achievements (Jarvis \& Baloyi, 2020; Nguyễn \& Nguyễn, 2017). HOTS assessments use instruments that require students to apply high-level skills in its completion.

There are several elements of HOTS including problem-solving skills, critical thinking skills, and creative thinking skills. HOTS as problem solver aims at determining problems, exploring problems, planning solutions, implementing plans, examining solutions, and evaluating solutions. Referring to the Bloom's criteria, critical thinking and creative thinking skills are the combination of knowledge and cognitive process. The critical and creative thinking stages in Bloom's taxonomy include C5 and C6 (Anderson \& Bloom, 2001; Darmawan \& Sujoko, 2013; Rifâ et al., 2018; Supeno \& Alhamidi, 2017; Yuliandini et al., 2019). 
The development of thinking skills requires practice on forming hypotheses, compiling explanations, making generalizations, finding patterns, and documenting findings along with real evidences (Eggen, 2016). The implementation of student-centered learning strategy is needed to trigger students to think at high order levels. Students have the opportunity to observe, ask, reason, try, and communicate; therefore it can stimulate their creativity and satisfy the expectations of 2013 curriculum (Budiyanto et al., 2016). Effective learning strategies will help students achieve high order thinking skills (Nelson \& Crow, 2014). Learning development that concerns on high order thinking skills should focus on the levels of thinking according to the Bloom's taxonomy (Abosalem, 2016).

HOTS activities can help students to seek new knowledge using inductive and deductive reasoning to identify and explore a subject (Lestari et al., 2016). Therefore, as stated in the objectives of 2013 curriculum, students will not only be able to know, comprehend, and apply knowledge, but they must also be able to analyze, evaluate, and even create something. However, it does not mean that the role of teachers can be ignored in establishing students' knowledge. Teachers can train students to acquire high order thinking skill as the objective of 2013 curriculum (Rapih \& Sutaryadi, 2018; Yuliandini et al., 2019). Students could have higher order thinking skills if the teachers conduct the classes using HOTS-based learning and use HOTS-based questions for assessment (Barrat, 2014; Brookhart, 2010). The high order thinking skills mentioned here are critical thinking reflective, metacognitive, and creative thinking. This is in line with the objectives of 2013 curriculum in PP No. 17/2010 to prepare Indonesian people to have the life skills and to give contribution in the society, country, and world civilization.

In relation to HOTS activities, the test questions are developed referring to the HOTS learning theory elaborated by the Bloom's revised taxonomy as implemented on the 2013 curriculum. Now, teachers generally have not developed assessments that let students think at the higher level. As reported by Herawati \& Hamdu (2014) and Hanifah (2019), assessments used at schools are not yet developed to improve the students' high order thinking skills (Hanifah, 2019; Herawati \& Hamdu, 2014). It is necessary to generate critical thinking skills through learning objectives, inquiry methods, exercises, comprehension improvements, feedbacks, and learning assessments.

The urgency of HOTS becomes stronger when The Partnership of 21st century skills (2011) formulated the 21 st century learning framework. In this framework, academic contents are in the form of 3rs (writing, reading and arithmetic) and 4cs (critical thinking, problem solving, collaboration, creativity and innovation); these are very important skills in the $21^{\text {st }}$ 
century learning activities (DuBay, 2020; Pease, 2018; Richardson, 2015). In reference to this framework, HOTS can be used to answer the 21st century learning challenges. In addition, through HOTS, students will be accustomed to think critically and creatively on both decision making and problem solving related to analyzing, evaluating, and creating (Anderson \& Krathwohl, 2010; Ichsan et al., n.d.; Sugandi \& Ruhimat, 2021).

Creating HOTS thinking style on students requires learning process that can accommodate the students' development. The students' HOTS can be stimulated through active learning, student-centered learning, generating curiosity, and HOTS-based assessment. The main emphasis to stimulate HOTS in learning activities is on the student-centered learning process.

Research related to HOTS has been conducted by Widodo et al. (2019) who looked into the analysis of HOTS-charged contents in the student book of curriculum 2013. The study found that the student book comprised of $36 \%$ of the LOTS load and $64 \%$ of the HOTS load, indicating that the HOTS load was higher than the LOTS load. Kusuma (2017) investigated the development of HOTS instrument of assessment in Physics Study. The result of the study found that the HOTS assessment instrument was effective in training the students' HOTS and measuring the students' thinking skills. Ichsan, et al. looked into the HOTS of elementary to master degree students in environmental learning. The results showed that students overall were in a very low HOTS category. On a scale of 0-100, The HOTS scores of the elementary school students (22.3) were still higher than the junior high school students (20.2). Meanwhile, the HOTS scores of the university students were 19.9-21.4. This showed that it was necessary to enhance the students' HOTS in the learning process through developing learning media, materials, models, and strategies. Acesta \& Sumantri (2020) investigated the development of natural science learning models based on multiple intelligences to improve higher order thinking skills of elementary school students. The results showed that the model developed was valid.

Looking at the results of previous studies, there were still many problems faced by students in understanding and solving HOTS questions properly. The previous studies were mostly conducted in the high school context, involving students with a higher level of thinking. Therefore, further research investigating the HOTS skills of students at the elementary school level is needed. From survey results in several Islamic Elementary Schools in Salatiga, most of the teachers have not implemented HOTS-based learning and assessment in Science classes so that students are not familiar with the types of HOTS questions. Therefore, this research aims to investigate the Islamic Elementary School students' ability in 
answering HOTS-based questions. It is hoped that this study could encourage teachers to develop HOTS in the teaching and learning process in order to promote the student's thinking ability at higher level.

\section{METHODS}

Using descriptive quantitative with purposive sample technique, this study involved 13 Islamic Elementary Schools in Salatiga City, both private and public schools. Based on the level, the schools were categorized as low, medium, and high. The three levels were used in this research. In the pre-field stage, the researcher conducted a preliminary survey. During this process, the researcher carried out field study of the research subjects and compiled the research design. In the field work stage, the researcher set the research setting for data collection. The next stage was data analysis. The researcher implemented a series of analysis to analyze the quantitative and qualitative data. The final stage was evaluation and reporting, which was done after analyzing the research data.

Data were collected using tests, questionnaires, and Focus Group Discussion (FGD). The test materials used were natural science subjects. The type of the test was a HOTS multiple choice with 4 options. This research provided important information related to the students' HOTS abilities in the Islamic elementary school context. The students were tested with Science questions in the form of multiple choices with the composition of HOTS, MOTS, and LOTS. The FGD in this study involved three experts, consisting of material experts, learning evaluation experts, and teachers of natural science subjects. FGD aims to validate test questions related to construction, substance, and language. Before being tested, the questions were validated by three experts who came from Islamic Elementary School Teacher Study Program (PGMI) lecturers of State Institute of Islamic Studies Salatiga. Expert validation results of the test instrument can be seen in Table 1.

Table 1. Validation of Test Questions by Experts

\begin{tabular}{|c|c|c|c|c|c|c|c|c|}
\hline \multirow[t]{2}{*}{ No } & \multirow[t]{2}{*}{ Aspects } & \multirow[t]{2}{*}{ Indicators } & \multicolumn{3}{|c|}{ Values } & \multirow{2}{*}{$\frac{3}{3}$} & \multirow[t]{2}{*}{ Score } & \multirow[t]{2}{*}{ Category } \\
\hline & & & Val 1 & Val 2 & Val 3 & & & \\
\hline 1. & Substance & $\begin{array}{l}\text { Substance } \\
\text { compatibility with } \\
\text { competence }\end{array}$ & 4 & 4 & 4 & 4 & A & Very Good \\
\hline 2. & Construction & Construction accuracy & 4 & 4 & 3 & 3,7 & A & Very Good \\
\hline \multirow[t]{4}{*}{3.} & Language & $\begin{array}{l}\text { a. Compatibility } \\
\text { with POEBI }\end{array}$ & 4 & 3 & 4 & 3,7 & A & Very Good \\
\hline & & $\begin{array}{l}\text { b. Language } \\
\text { suitability }\end{array}$ & 3 & 3 & 3 & 3 & $\mathrm{~B}$ & Good \\
\hline & Total & & 15 & 14 & 14 & 14,4 & & \\
\hline & Mean & & 3,75 & 3,5 & 3,5 & 3,6 & $\mathrm{~A}$ & Very Good \\
\hline
\end{tabular}


Criteria:

$\begin{array}{llll}\text { 1. } & \mathrm{X} \geq 3,10 & \text { A } & \text { Very Good } \\ \text { 2. } & 3,10<\mathrm{X} \leq 2,50 & \mathrm{~B} & \text { Good } \\ \text { 3. } & 2,50<\mathrm{X} \leq 1,90 & \mathrm{C} & \text { Average } \\ \text { 4. } & \mathrm{X}<1,90 & \mathrm{D} & \text { Poor }\end{array}$

$\mathrm{X}$ : Scoring

(Anam, 2020)

Looking at Table 1, the aspects of substance, construction, and language generally got a very good score (A). However, improvements were needed in terms of the language aspect since students still found it difficult to understand the question. The language used was still too advanced so it would be difficult for elementary students to understand it. Revisions of the questions were needed to improve the language used so that it could be understood by students at the elementary school level. The data analysis technique used was descriptive analysis method with the percentile formula.

\section{RESULTS AND DISCUSSION}

The following research results show the Islamic Elementary School students' ability in answering questions given by the teachers. The students' scores can be seen in Table 2 .

Table 2. The students' ability to answer questions

\begin{tabular}{llll}
\hline Score & Frequency & $\begin{array}{l}\text { Low Group } \\
\text { Percentage }(\%)\end{array}$ & $\begin{array}{l}\text { High Group } \\
\text { Percentage }(\%)\end{array}$ \\
\hline 2 & 3 & 2.5 & \\
3 & 6 & 5 & \\
4 & 21 & 17.5 & \\
5 & 33 & 27.5 & \\
6 & 15 & & 12.5 \\
7 & 24 & & 20 \\
8 & 15 & & 12.5 \\
9 & 3 & & 2.5 \\
\hline Total & 120 & 52.5 & 47.5 \\
\hline
\end{tabular}

According to Table 2, the students' lowest score was on the question number $2(2.5 \%)$ whereas the highest score was on the question number 9 (2.5\%). Furthermore, it can be seen that the scores obtained are not regular and are arranged into an order of distribution, from the lowest score to the highest score (Fatimah \& Alfath, 2019). Based on the results, the mean value obtained was 5.65. From the results of the mean value, it was categorized as low because the value was still below 6 . The highest score was on the question number $5(27.5 \%)$.

Based on the results of the scores obtained by students, of the 120 students as samples there were 63 students who scored below 6 or $52.5 \%$. The number of students who scored $\geq 6$ was 57 students $(47.5 \%)$. Regarding these results, more than half of the students scored $\geq 6$. 
The students who scored $\geq 6$ were classified into the high group category, while students whose grades below 6 were classified into the low group category. More than half of Islamic Elementary School students were in the low group category. The students' ability to answer various question categories indicates mixed results. It can be seen in Table 3.

Table 3. Students' Ability to Answer Various Question Categories

\begin{tabular}{|c|c|c|c|c|c|c|}
\hline No & Questio & MIK & MI B & MI D & MI P & Mean \\
\hline$\overline{1}$ & LOTS & 0.9 & 0.2 & 0.4 & 0.9 & 0.6 \\
\hline 2 & LOTS & 0.9 & 1 & 0.8 & 1 & 0.925 \\
\hline 3 & HOTS & 0.5 & 0.2 & 0.6 & 0.5 & 0.45 \\
\hline 4 & MOTS & 0.8 & 0.4 & 0.8 & 0.6 & 0.65 \\
\hline 5 & MOTS & 0.4 & 0.2 & 0.2 & 0.6 & 0.35 \\
\hline 6 & LOTS & 1 & 0.8 & 0.7 & 0.8 & 0.825 \\
\hline 7 & MOTS & 0.8 & 0.6 & 0.4 & 0.7 & 0.625 \\
\hline 8 & LOTS & 0.8 & 0.6 & 0.9 & 0.9 & 0.8 \\
\hline 9 & HOTS & 0.6 & 0.6 & 0.4 & 0.2 & 0.45 \\
\hline 10 & HOTS & 0.2 & 0 & 0.1 & 0 & 0.075 \\
\hline
\end{tabular}

Description: Index Category: 0 to 1

From the data above, in LOTS category, the students' scores ranged from 0.6 to 0.9 (high). It means that more than half of the students can answer questions in LOTS category. In MOTS questions category, the index of students' abilities was 0.35 to 0.65 . The students' ability to answer MOTS question category was $35 \%$ to $65 \%$ (medium). In HOTS questions category, the index of the students' ability was 0.075 to 0.45 . In HOTS category, the students' abilities were at the low level, because the number of students who were able to answer questions correctly was still below 50\%. It implies that most Islamic Elementary School students in Salatiga were not able to transfer knowledge into problem solving. Hasyim \& Andreina (2019) stated that the students' HOTS ability was determined by the student's ability to solve open problems; the higher the ability in solving open problem questions, the higher HOTS indicator they achieved. Students with high HOTS ability are able to fulfil the analysis, evaluation, and creation indicators. Students with medium HOTS ability can complete the analysis and evaluation indicators. Students with low HOTS ability only reach the analysis indicator. Thus, it is important to maintain the creativity of students. Lin's research (2017) on the threshold effects of creative problem-solving attributes on reactivity in the math abilities of Taiwanese upper elementary students shows that there are three creative problem-solving typologies: high, medium, and low. The development of balanced attributes can be an important consideration in nurturing creativity in children. Bakry (2015) added that the student who has high math ability is able to create meaning, make opinion, and conclude, 
while the student who has medium math ability is able to create meaning, make opinion but cannot conclude, and the student who has low math ability is not able to create meaning and cannot conclude. Goethals (2013) added that HOTS was at the top of the Bloom's cognitive taxonomy; it aimed to equip students on knowledge transfer, thinking ability, applying the developed knowledge and skills that they learn in schools on new contexts. There are several advantages for students if they have HOTS abilities. They think more logically, systematically, critically, analytically, creatively, and evaluative. Students could have broad insights and be more critical to deal with problems and solutions.

From the interview results, it is known that the students' obstacles in achieving HOTS abilities are due to the dearth of references, the lack of understanding concepts, the difficulty in answering multiple choices questions and understanding HOTS questions. This is in line with Intan et al. (2020) who found that students did not understand HOTS question. Arifuddin (2019) stated that the elementary school students did not master the mathematical concept. Saraswati \& Agustika (2020); Arifuddin (2020) added that elementary school students experienced problems in compiling mathematical sentences for essay questions. Abdullah (2015) added that students faced problems to correlate the information and implementation of strategies used in solving mathematical problems involving HOTS. Issues on improving the students' HOTS abilities are that: there is a lack of teachers' comprehension on the concept and implementation of HOTS in learning activities; training and mentoring on HOTS are still limited; and references are still limited. This makes it difficult for teachers to determine questions that meet the HOTS standard, create HOTS questions, and choose the relevant learning strategies.

There are supporting factors for improving the students' HOTS abilities at Islamic Elementary Schools in Salatiga such as: the teachers' positive perceptions on the implementation of HOTS-based learning and assessment in Islamic Elementary Schools, the support and commitment of Principal on the improvement of education quality, especially the application of HOTS-based learning in Islamic Elementary Schools, and the supporting infrastructure.

\section{CONCLUSION}

The HOTS ability of the Islamic Elementary School students is still low. It is influenced by several factors, including the dearth of references, the lack of understanding on the concepts, the difficulty in choosing answers on multiple choices questions and in understanding HOTS questions. Therefore, the learning process should be directed to develop critical, creative, collaborative, and communicative thinking skills, so that the students' HOTS 
abilities could improve. In addition, the commitment of teachers and principal in implementing HOTS-based learning and assessment is very important.

\section{REFERENCES}

Abdullah, A., Abidin, N., Science, M. A.-A. S., \& 2015, undefined. (2015). Analysis of students' errors in solving Higher Order Thinking Skills (HOTS) problems for the topic of fraction. Researchgate.Net, 11(21). https://doi.org/10.5539/ass.v11n21p133

Abosalem, Y. (2016). Assessment techniques and students' higher-order thinking skills. International Journal of Secondary Education, 4(1), 1.

Acesta, A., \& Sumantri, M. S. (2020). Development of Natural Science Learning Models Based on Multiple Inteligences to Improve Higher Order Thinking Skills in Elementary Schools. Journal of Physics: Conference Series, 1477(4), 42036.

Anam, R. S. (2020). The Analysis of Science Process Skills on Pre-Service Elementary School Teachers. Al Ibtida: Jurnal Pendidikan Guru MI, 7(2), 226. https://doi.org/10.24235/al.ibtida.snj.v7i2.6470

Anderson, L. W., \& Bloom, B. S. (2001). A taxonomy for learning, teaching, and assessing: A revision of Bloom's taxonomy of educational objectives. Longman,.

Anderson, L. W., \& Krathwohl, D. R. (2010). Pembelajaran, pengajaran, dan asesmen. Yogyakarta: Pustaka Pelajar.

Arifuddin, A. (2019). Students' Critical and Creative Thinking Skills on Mathematics Learning in Madrasah Ibtidaiyah. Auladuna: Jurnal Pendidikan Dasar Islam, 6(1), 3849.

Arifuddin, A. (2020). The Analysis of Critical Thinking Skills of Primary School Teacher Candidates in Solving Mathematical Problems. Al Ibtida: Jurnal Pendidikan Guru MI, 7(1), 46-55.

Azwar, S. (2013). Metode penelitian (Edisi ke-1). Yogyakarta: Pustaka Pelajar.

Bakry, M. N. B. B. (2015). The Process of Thinking among Junior High School Students in Solving HOTS Question. International Journal of Evaluation and Research in Education, 4(3), 138-145.

Barrat, C. (2014). Higher Order Thinking And Assessment. International Seminar on current issues in Primary Education. PGSD Study Program, Muhammadiyah University of Makassar.

Brookhart, S. M. (2010). How to assess higher-order thinking skills in your classroom. ASCD.

Budiyanto, M. A. K., Waluyo, L., \& Mokhtar, A. (2016). Implementation of scientific approach in education in Primary Education in Malang. Proceeding Biology Education Conference, 13(1), 46-51.

Darmawan, I. P. A., \& Sujoko, E. (2013). Revisi Taksonomi Pembelajaran Benyamin S. Bloom. Satya Widya, 29(1), 30-39.

DuBay, R. (2020). A Musically Emebedded Curriculum for Rural Elementary Schools. Liberty University.

Eggen, P. (2016). Strategi dan model pembelajaran: Mengajarkan konten dan ketrampilan berpikir. 
Fanani, M. Z. (2018). Strategi pengembangan soal hots pada kurikulum 2013. Edudeena: Journal of Islamic Religious Education, 2(1).

Fatimah, L. U., \& Alfath, K. (2019). Analisis Kesukaran Soal, Daya Pembeda dan Fungsi Distraktor. Journal Al-Manar, 8(2), 37-64.

Goethals, P. L. (2013). The pursuit of higher-order thinking in the mathematics classroom: a review. United States Military Academy, West Point, NY.

Hanifah, N. (2019). Pengembangan instrumen penilaian Higher Order Thinking Skill (HOTS) di sekolah dasar. Current Research in Education: Conference Series Journal, 1(1), 5.

Hasyim, M., \& Andreina, F. K. (2019). Analisis high order thinking skill (hots) siswa dalam menyelesaikan soal open ended matematika. FIBONACCI: Jurnal Pendidikan Matematika Dan Matematika, 5(1), 55-64.

Herawati, R., \& Hamdu, G. (2014). Pengembangan Asesmen Hots pada Pembelajaran Berbasis Masalah Tema Bermain Dengan Benda-Benda Di Sekitar. PEDADIDAKTIKA: Jurnal Ilmiah Pendidikan Guru Sekolah Dasar, 1(2), 151-159.

Ichsan, I., Sigit, D., Miarsyah, M., Ali, A., ... W. A.-E. J. of, \& 2019, undefined. (n.d.). HOTS-AEP: Higher Order Thinking Skills from Elementary to Master Students in Environmental Learning. ERIC. Retrieved October 18, 2021, from https://eric.ed.gov/?id=EJ1231652

Ilham, N. W., Jabu, B., \& Korompot, C. A. (2020). Analysis of Higher-Order Thinking Skills (Hots) Items in Senior High School English National Examination 2019. ELT Worldwide: Journal of English Language Teaching, 7(2), 157-162.

Intan, F. M., Kuntarto, E., \& Alirmansyah, A. (2020). Kemampuan Siswa dalam Mengerjakan Soal HOTS (Higher Order Thinking Skills) pada Pembelajaran Matematika di Kelas V Sekolah Dasar. JPDI (Jurnal Pendidikan Dasar Indonesia), 5(1), 6-10.

Jarvis, M. A., \& Baloyi, O. B. (2020). Scaffolding in reflective journaling: A means to develop higher order thinking skills in undergraduate learners. International Journal of Africa Nursing Sciences, 12(December 2019), 100195. https://doi.org/10.1016/j.ijans.2020.100195

Kusuma, M. D. (2017). Pengembangan Perangkat Instrumen Asesmen Higher Order Thinking Skill (HOTS) dalam Pembelajaran Fisika Siswa SMA pada Materi Fluida Statis. UNIVERSITAS LAMPUNG.

Lestari, A., Saepulrohman, A., \& Hamdu, G. (2016). Pengembangan soal tes berbasis hots pada model pembelajaran latihan penelitian di sekolah dasar. PEDADIDAKTIKA: Jurnal Ilmiah Pendidikan Guru Sekolah Dasar, 3(1), 74-83.

Merta Dhewa, K., Rosidin, U., Abdurrahman, A., \& Suyatna, A. (2017). The development of Higher Order Thinking Skill (Hots) instrument assessment in physics study. IOSR Journal of Research \& Method in Education (IOSR-JRME), 7(1), 26-32.

Nelson, L. P., \& Crow, M. L. (2014). Do Active-Learning Strategies Improve Students' Critical Thinking?. Higher Education Studies, 4(2), 77-90.

Nguyễn, T. M. T., \& Nguyễn, T. T. L. (2017). Influence of explicit higher-order thinking skills instruction on students' learning of linguistics. Thinking Skills and Creativity, 26, 113-127. https://doi.org/10.1016/j.tsc.2017.10.004

Pease, P. M. (2018). Teaching and Learning to Risk: Design Pedagogy as a Catalyst for Innovation and Creative Risk-Taking in Secondary School Learning Environments. North Carolina State University. 
Rapih, S., \& Sutaryadi, S. (2018). Perpektif guru sekolah dasar terhadap Higher Order Tinking Skills (HOTS): pemahaman, penerapan dan hambatan. Premiere Educandum: Jurnal Pendidikan Dasar Dan Pembelajaran, 8(1), 78-87.

Richardson, W. (2015). From master teacher to master learner. Solution Tree Press.

Rifâ, A., Serevina, V., \& Delina, M. (2018). The development of High Order Thinking Skills (HOTS) assessment instrument for temperature and heat learning. Jurnal Penelitian \& Pengembangan Pendidikan Fisika, 4(1), 19-26.

Saraswati, P. M. S., \& Agustika, G. N. S. (2020). Kemampuan Berpikir Tingkat Tinggi Dalam Menyelesaikan Soal HOTS Mata Pelajaran Matematika. Jurnal Ilmiah Sekolah Dasar, 4(2), 257-269.

Sugandi, D., \& Ruhimat, M. (2021). The Urgency of HOTS-Oriented Learning and Assessment Towards Quality of Education in Facing Indonesia Sustainable Development Goals (SDGs) 2030. 5th Asian Education Symposium 2020 (AES 2020), 237-250.

Supeno, S., \& Alhamidi, L. A. (2017). Reading Strategies As Development Model English Cognition of Senior High School Students. IJEE (Indonesian Journal of English Education), 4(1), 84-96.

Tobari, T., Kristiawan, M., \& Asvio, N. (2018). The Strategy of Headmaster on Upgrading Educational Quality in Asean Economic Community (AEC) Era. International Journal of Scientific Dan Technology Research, 7, 72-79.

Widodo, A., Indraswati, D., Radiusman, R., Umar, U., \& Nursaptini, N. (2019). Analisis Konten HOTS dalam Buku Siswa Kelas V Tema 6 "Panas dan Perpindahannya" Kurikulum 2013. Madrasah: Jurnal Pendidikan Dan Pembelajaran Dasar, 12(1), 113.

Widyawati, A., Dwiningrum, S. I. A., \& Rukiyati, R. (2021). Pembelajaran ethnosciences di era revolusi industri 4.0 sebagai pemacu Higher Order Thinking Skills (HOTS). Jurnal Pembangunan Pendidikan: Fondasi Dan Aplikasi, 9(1).

Yuliandini, N., Hamdu, G., \& Respati, R. (2019). Pengembangan soal tes berbasis higher order thinking skill (HOTS) taksonomi bloom revisi di sekolah dasar. PEDADIDAKTIKA: Jurnal Ilmiah Pendidikan Guru Sekolah Dasar, 6(1), 37-46. 